University of Nebraska - Lincoln

DigitalCommons@University of Nebraska - Lincoln

USDA National Wildlife Research Center - Staff Publications
U.S. Department of Agriculture: Animal and Plant Health Inspection Service

2005

Status of oral rabies vaccination in wild carnivores in the United States

\author{
Dennis Slate \\ USDA, APHIS, Wildlife Services \\ Charles E. Rupprecht \\ Centers for Disease Control and Prevention \\ Jane A. Rooney \\ West Virginia Department of Health and Human Resources \\ Dennis Donovan \\ Ontario Ministry of Natural Resources \\ Donald H. Lein \\ Cornell University
}

See next page for additional authors

Follow this and additional works at: https://digitalcommons.unl.edu/icwdm_usdanwrc

Part of the Life Sciences Commons

Slate, Dennis; Rupprecht, Charles E.; Rooney, Jane A.; Donovan, Dennis; Lein, Donald H.; and Chipman, Richard B., "Status of oral rabies vaccination in wild carnivores in the United States" (2005). USDA National Wildlife Research Center - Staff Publications. 1905.

https://digitalcommons.unl.edu/icwdm_usdanwrc/1905

This Article is brought to you for free and open access by the U.S. Department of Agriculture: Animal and Plant Health Inspection Service at DigitalCommons@University of Nebraska - Lincoln. It has been accepted for inclusion in USDA National Wildlife Research Center - Staff Publications by an authorized administrator of DigitalCommons@University of Nebraska - Lincoln. 


\section{Authors}

Dennis Slate, Charles E. Rupprecht, Jane A. Rooney, Dennis Donovan, Donald H. Lein, and Richard B. Chipman 


\title{
Status of oral rabies vaccination in wild carnivores in the United States
}

\author{
Dennis Slate ${ }^{\mathrm{a}, *}$, Charles E. Rupprecht ${ }^{\mathrm{b}}$, Jane A. Rooney ${ }^{\mathrm{c}}$, \\ Dennis Donovan ${ }^{d}$, Donald H. Lein ${ }^{e}$, Richard B. Chipman ${ }^{f}$ \\ a USDA, APHIS, Wildlife Services, 59 Chenell Drive, Suite 7, Concord, NH 03301, USA \\ ${ }^{\mathrm{b}}$ Centers for Disease Control and Prevention, Atlanta, GA, USA \\ ${ }^{c}$ West Virginia Department of Health and Human Resources, Charleston, WV, USA \\ d Ontario Ministry of Natural Resources, Peterborough, Ont., Canada \\ e Cornell University, Ithaca, NY, USA \\ ${ }^{\mathrm{f}}$ USDA, APHIS, Wildlife Services, Castleton, NY, USA
}

\begin{abstract}
Persistence of multiple variants of rabies virus in wild Chiroptera and Carnivora presents a continuing challenge to medical, veterinary and wildlife management professionals. Oral rabies vaccination (ORV) targeting specific Carnivora species has emerged as an integral adjunct to conventional rabies control strategies to protect humans and domestic animals. ORV has been applied with progress toward eliminating rabies in red foxes (Vulpes vulpes) in western Europe and southern Ontario, Canada. More recently since 1995, coordinated ORV was implemented among eastern states in the U.S.A. to prevent spread of raccoon (Procyon lotor) rabies and to contain and eliminate variants of rabies virus in the gray fox (Urocyon cinereoargenteus) and coyote (Canis latrans) in Texas. In this paper, we describe the current cooperative ORV program in the U.S.A. and discuss the importance of coordination of surveillance and rabies control programs in Canada, Mexico and the U.S.A. Specifically, several priorities have been identified for these programs to succeed, which include additional oral vaccines, improved baits to reach target species, optimized ORV strategies, effective communication and legal strategies to limit translocation across ORV barriers, and access to sufficient long-term funding. These key priorities must be addressed to ensure that ORV has the optimal chance of achieving long range programmatic goals of eliminating specific variants of rabies virus in North American terrestrial carnivores.
\end{abstract}

(C) 2005 Elsevier B.V. All rights reserved.

Keywords: Rabies virus; Terrestrial rabies; Oral rabies vaccination; Bait; Barrier; Vaccinia; Carnivora; Carnivores; Raccoon; Coyote; Gray fox; Red fox; Skunk; Bat

\section{Contents}

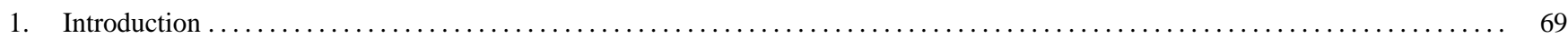

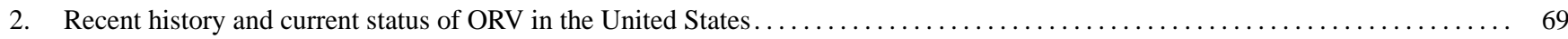

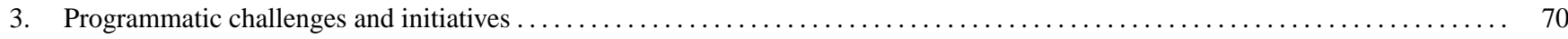

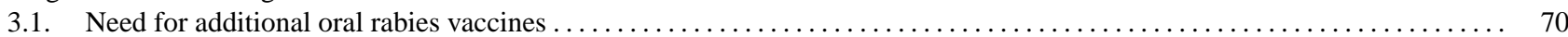

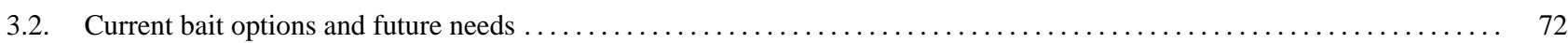

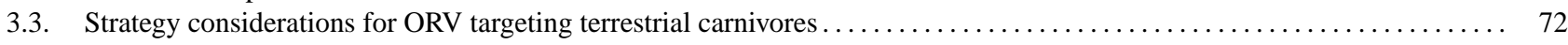

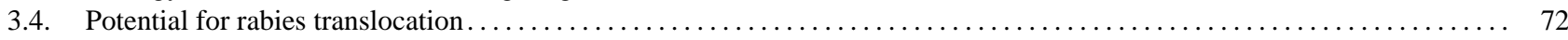

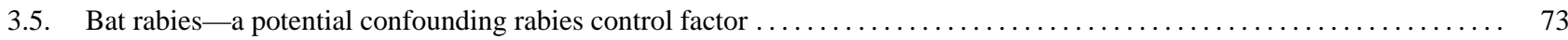

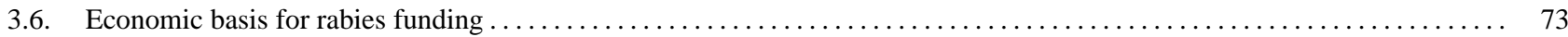

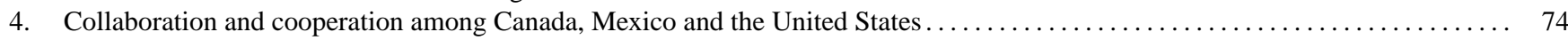

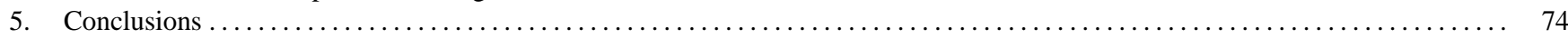

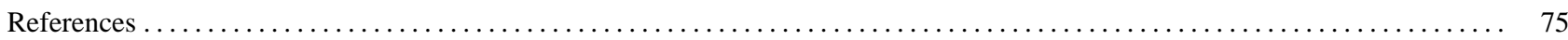

* Corresponding author. Tel.: +1 603223 9623; fax: +1 6032290504 .

E-mail address: dennis.slate@ aphis.usda.gov (D. Slate). 


\section{Introduction}

In countries where the control of canine rabies has been achieved, wildlife serves as a dominant reservoir. Modern prevention and control techniques for wildlife rabies may serve as a model for intervention with other zoonotic diseases. Oral rabies vaccination (ORV) was proven feasible in captive red foxes in the U.S. in 1969 (Baer et al., 1971). Thereafter, ORV targeting rabies in red foxes began in Europe in 1977 (Steck et al., 1982), and continues in several Europeans countries with the goal of disease elimination (Aubert et al., 1994; Stohr and Meslin, 1996; Wandeler, 2000; Zanoni et al., 2000). ORV was initiated in Ontario, Canada in 1989 (MacInnes et al., 2001) and continues with the goal of eliminating an artic fox (Alopex lagopus) variant of rabies virus in red foxes (MacInnes and LeBer, 2000).

Experimental ORV programs began in the U.S.A. in the mid-1990s (Bigler, 1997; Robbins et al., 1998; Fearneyhough et al., 1998; Smith et al., 1999; Olson et al., 2000; USDA, 2003) after field safety and efficacy trials were successfully completed on Parramore Island, Virginia in 1990 (Hanlon et al., 1998) and near Williamsport, Pennsylvania in 1991 (Hanlon and Rupprecht, 1998) and Cape May, New Jersey from 1992 and 1993 (Roscoe et al., 1998). Federal support for coordinated ORV has provided the impetus to establish cooperative programs in 15 eastern states to prevent the spread of raccoon rabies and to create programs in Texas to prevent rabies in coyotes and a unique variant of rabies in gray foxes. While these programs show promise, several challenges need to be addressed to better ensure that the long-term programmatic goal of rabies elimination in terrestrial wildlife may be achieved. In this paper, we discuss the current status of ORV in the U.S.A., initiatives to address challenges facing ORV, and the role of international cooperation and coordination with Canada and Mexico in meeting North American rabies management goals.

\section{Recent history and current status of ORV in the United States}

In 1998, the U.S. Department of Agriculture, Animal and Plant Health Inspection Service, Wildlife Services (APHISWS) received its first federal appropriation to cooperate in existing ORV projects, expand ORV to states of strategic importance in preventing the spread of specific terrestrial variants of the rabies virus, and to assist in coordinating cooperative interstate ORV projects. The first initiative taken to meet these objectives was to form a National Rabies Management Team, composed of diverse expertise from State agencies responsible for public health, agriculture, and wildlife, Centers for Disease Control and Prevention (CDC) and other Federal agencies and universities to strategically plan, establish program priorities and goals, and evaluate program progress. This National Rabies Manage-
Table 1

Ten interdisciplinary teams within the National Rabies Management Team charged with evaluating critical ORV subject areas and providing recommendations for cooperative rabies control planning

Baiting support: air and ground

Baiting strategies/GIS planning

Communications planning

Contingency action planning

Economic analysis

NEPA compliance

ORV evaluation

Research prioritization

Surveillance/laboratory support

Vaccine/bait/biomarker

ment Team is composed of 10 focus teams charged with providing guidance and recommendations for topics integral to national ORV, ranging from National Environmental Policy Act (NEPA [NEPA, 1969]) compliance to research prioritization (Table 1).

Between 1998 and 2003, ORV expanded from New York, Ohio, Texas and Vermont (smaller programs were also in place in Florida, Maryland, and Massachusetts) to include 16 states (Figs. 1 and 2). Vaccination zones were integrated with natural geographic features such as large lakes, rivers and poorer raccoon habitats at high elevations where practical to bolster vaccination barriers and reduce the overall cost of rabies control. By 2003, increased federal support had facilitated nearly full implementation of the containment barrier for raccoon rabies in the eastern U.S. In addition, approximately $96 \mathrm{~km}$ of western Pennsylvania had been treated where raccoon rabies has been enzootic for over a decade. This extension is designed to explore strategies to eliminate the raccoon variant of rabies virus. ORV was implemented to eliminate canine rabies (spread predominantly by coyotes) from south Texas. This goal was achieved in 2000 , but a $65 \mathrm{~km}$ wide maintenance vaccination barrier has been created along the Rio Grande to prevent re-infection from Mexico. This barrier was challenged in 2001 and 2004, underscoring its importance especially in the absence of more comprehensive rabies surveillance in the region. The containment barrier for gray fox rabies that was created solely with state funding in 1996 in west-central Texas was also restored with federal support to make up for decreased state funding. In 2003, approximately $180,000 \mathrm{~km}^{2}$ were treated with over 10 million vaccine-ladened baits in 16 states to target variants of rabies virus unique to the raccoon and gray fox, as well as the canine strain in coyotes along Texas-Mexico border (Figs. 1 and 2; Table 2).

The vision for the National ORV Program is to eliminate rabies in terrestrial carnivores. The immediate goals are to prevent specific variants of rabies virus in the raccoon and gray fox (strain unique to Texas) from spreading to new, uninfected areas (Slate et al., 2002). The long-range goal is to eliminate these variants from the U.S.A. as has been accomplished with rabies in the coyote in south Texas. Elimination 

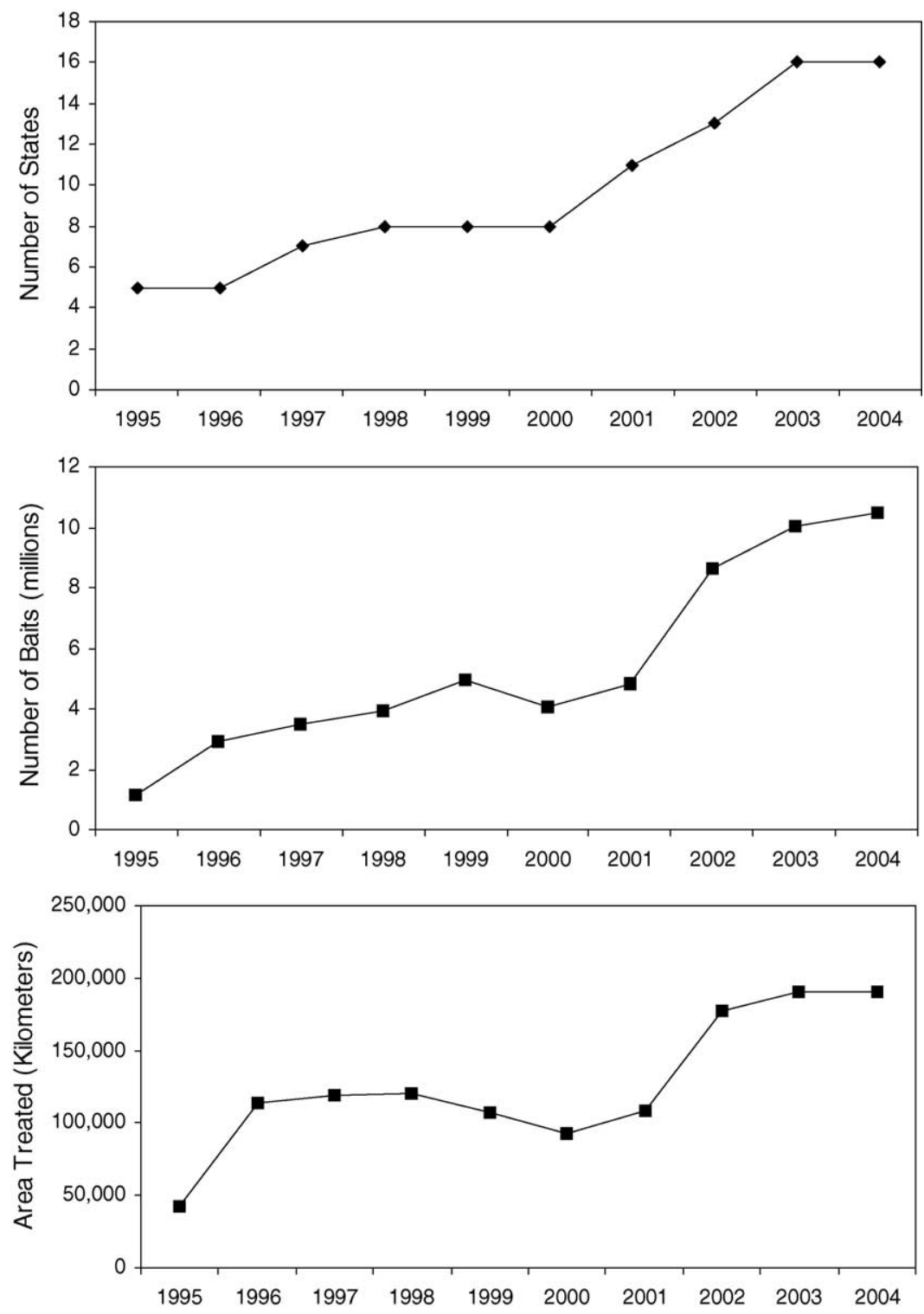

Fig. 1. Trends for the number of cooperating states, oral rabies baits distributed and area treated in the United States from 1995 to 2004.

is expected to be challenging, in part, because specific rabies virus variants may have been established for long periods of time in some geographic areas (e.g., raccoon rabies was first described in 1947 in Florida [Bigler et al., 1973]). Additional hurtles to success include the presence of a diverse meso-carnivore complex that serves as a reservoir for specific variants of the rabies virus and the presence of extraordinarily high densities of raccoons, in particular, that not infrequently occur in response to intentional feeding or access to human refuse that may facilitate rapid spread of rabies. True elimination cannot be achieved without international cooperation from Canada and Mexico. This task is much more formidable than the focus on ORV in the red fox alone, as conducted to date.

\section{Programmatic challenges and initiatives}

\subsection{Need for additional oral rabies vaccines}

Raboral V-RG ${ }^{\circledR}$ is the only oral rabies vaccine licensed for use in the U.S. It has not produced sufficient levels of population immunity in skunks (primarily Mephitis mephitis) in the wild at the current dose $\left(\geq 10^{7.7} \mathrm{TCID}_{50} / \mathrm{ml}\right)$, and V-RG may be less effective in skunks than other species (Tolson et al., 1987). Skunks are a major contributor to rabies in North America. Thirty-eight percent of cases associated with the raccoon variant of rabies virus involved skunks in 2001 (Krebs et al., 2002), a trend that has raised concerns about an independent maintenance cycle for raccoon rabies in skunks 


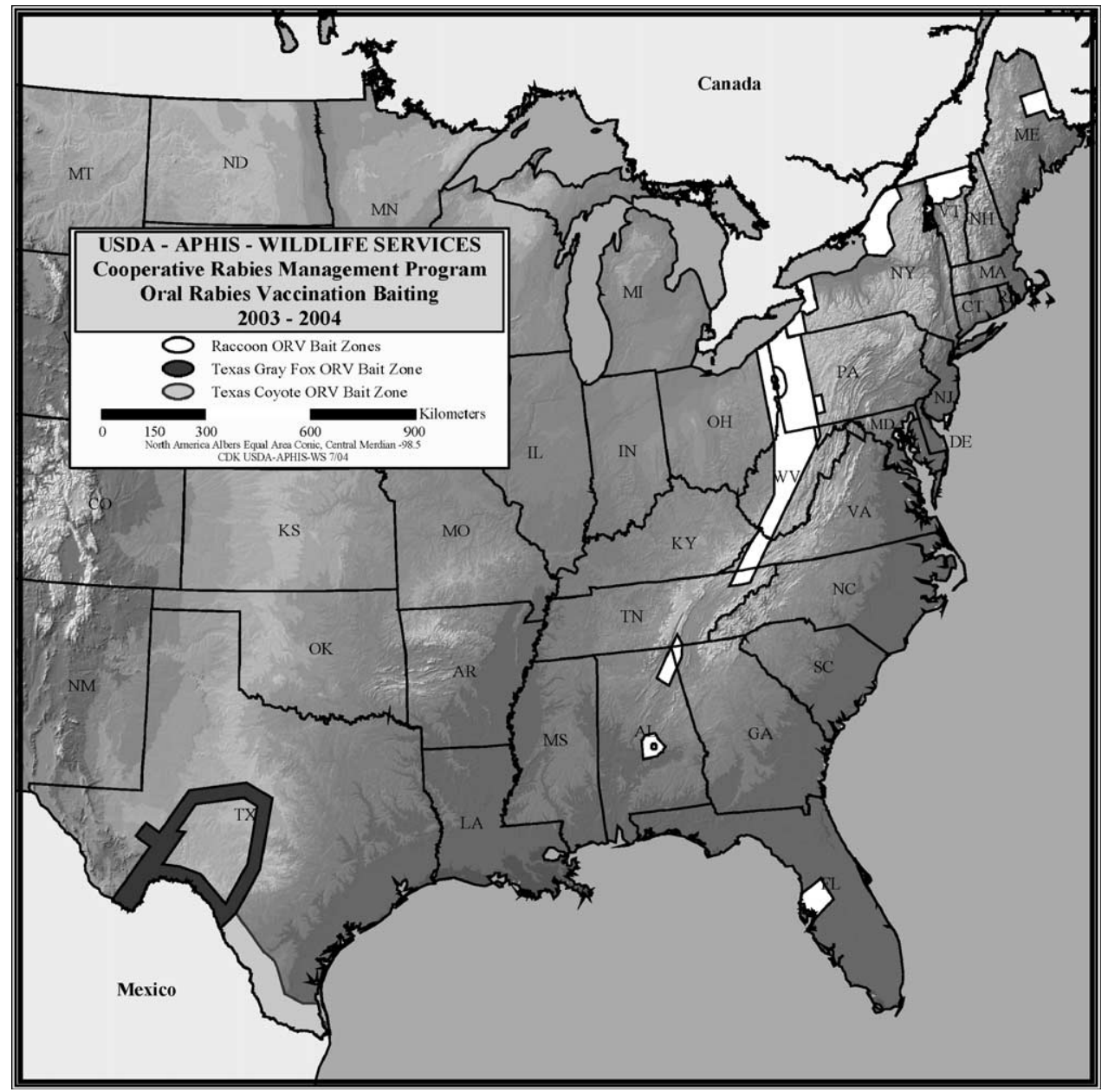

Fig. 2. Oral vaccination zones targeting raccoon, gray fox (in Texas) and canine (coyotes) variant of the rabies virus in the United States in 2004.

Table 2

Summary of ORV bait distribution by species and state for 2003

\begin{tabular}{llr}
\hline State & Area baited $\left(\mathrm{km}^{2}\right)$ & No. of baits distributed \\
\hline Raccoon & & \\
AL & 3215 & 175839 \\
FL & 6293 & 500507 \\
GA & 1058 & 69317 \\
ME & 4308 & 276104 \\
MA & 420 & 54822 \\
NH & 385 & 18140 \\
NJ & Cape May Co. & 39000 \\
NY & 19657 & 1367777 \\
OH & 8156 & 621148 \\
PA & 24900 & 2002005 \\
TN & 3232 & 231865 \\
VA & 5669 & 389667 \\
VT & 6403 & 327405 \\
WV & 25356 & 1702585 \\
Coyote & & \\
TX & 31080 & 700000 \\
Gray fox & & \\
TX & 49210 & 1800000 \\
Totals & 189342 & 10276181
\end{tabular}

(Guerra et al., 2003). The striped skunk may also help maintain the arctic fox variant (in red foxes) in southern Ontario (Nadin-Davis et al., 1999). The national rabies management goals of virus containment and elimination will likely remain elusive until an oral vaccine is licensed that is immunogenic in all terrestrial rabies reservoir species. In addition, skunk rabies virus, which has the broadest geographic distribution of all terrestrial rabies variants in the U.S.A. (Krebs et al., 1995) can currently be addressed only though local trap-vaccinaterelease (TVR) or population suppression programs.

At the close of 2003, almost 50 million doses of Raboral $\mathrm{V}-\mathrm{RG}^{\circledR}$ had been distributed across broad and diverse landscapes during the past decade with only one human vaccinia virus infection that resolved without lasting medical effects (Rupprecht et al., 2001). In spite of this field safety record, vaccinia virus, the vector for the rabies virus glycoprotein gene in Raboral V-RG ${ }^{\circledR}$, is in the family Poxiviridae (Van Regenmortel et al., 2000), which includes viruses that have come under greater scrutiny because of smallpox bioterrorism concerns (CDC, 2003a) and recent public health incidents involving monkeypox (CDC, 2003b). In addition, lack of competing vaccine manufacturers for $\mathrm{V}-\mathrm{RG}$ or other effective licensed vaccines may potentially impede business 
incentives for product improvements and competitive pricing.

In recognition of these critical issues, the Vaccine Team met in April 2003 to assess prospective oral vaccine candidates and potential regulatory obstacles. Funding was provided in 2003 to explore canine adenovirus (CAdV-2) (Van Regenmortel et al., 2000) as a vector for the rabies virus glycoprotein gene. Research has been underway since 2000 in Ontario on a human adenovirus (HAdV-5) as a potential vector for the rabies glycoprotein gene (Yarosh et al., 1996). In addition, there are other prospective recombinant and non-recombinant vaccines that may show promise for all terrestrial rabies reservoir species (Dietzschold et al., 2003). Development, safety and efficacy testing, and licensure of additional oral vaccines that are effective in all terrestrial rabies reservoir species remain among the highest priorities of the National Rabies Management Team.

\subsection{Current bait options and future needs}

Raboral V-RG ${ }^{\circledR}$ is currently delivered to raccoons in an extruded fishmeal polymer (FMP) bait $(3.18 \mathrm{~cm} H \times 3.18 \mathrm{~cm} L \times 1.91 \mathrm{~cm} \mathrm{~W}) \quad$ containing $150 \mathrm{mg}$ ( $1 \%$ of the $15 \mathrm{~g}$ bait) of tetracycline hydrochloride as a bone and tooth biomarker (MERIAL Ltd., Athens, Georgia). A plastic sachet containing $1.8 \mathrm{ml}$ of Raboral-V-RG ${ }^{\circledR}$ is affixed within the hollow of the hardened extruded bait by a wax plug. The same bait-vaccine combination is used in ORV programs targeting coyotes. An extruded, poultry-based, dog food polymer bait (otherwise identical to the fishmeal bait-vaccine combination) is used in ORV programs targeting gray foxes. A coated sachet (CS) bait, identical to the FMP sachet but coated directly with fishmeal, is also being evaluated in ORV programs in the northeastern U.S.A. Field and captive testing continues with the MERIAL FMP cylindrical bait, an Ontario bait (Artemis Technologies Inc., Guelph, Ont., Canada), and other viable candidates.

To ensure maximum immune levels in target populations, baits are needed that are attractive to target species and also facilitate puncture of the sachet or alternative vaccine containers when chewed. Ideally, a single bait would be available that possesses the requisite favorable attributes (Table 3) to reach all terrestrial rabies reservoir species with an equally high level of effectiveness. Given that the terrestrial rabies reservoirs include the striped skunk, raccoon, red and gray foxes, and coyote, differing foraging behaviors and animal size (physical capability for handling and chewing different size and shapes of baits), as well as the presence of different age cohorts in target populations (juvenile, sub-adult and adult) may require the availability of more than one bait option. Currently, MERIAL's CS appears to offer the best promise, at least as an interim bait, to reach all target species; however, additional captive and field studies are required and underway. Also, current production capability remains unresolved to meet potential market demand for the CS at this time.
Table 3

Optimal oral rabies bait characteristics

Size

Shape

Consistency

Attractive and persistent flavor

Attractive and persistent odor

Visible to rabies reservoir species

Invisible to non-targets and humans

Stable, does not melt or spoil

Matrix can withstand aerial drop

Matrix protects against vaccine leakage and from exposure to UV light

Mass not sufficient to cause injury or property damage from aerial distribution

Easily used for both aerial (rotary and fixed-wing) and hand baiting

18 month shelf-life without bait or biomarker degradation

Target species specific/terrestrial rabies reservoir specific

Can be surface-labeled

Food grade safe

Could be consumed by dogs without complication

Ideal bait matrix might combine both the vaccine and biomarker

Inexpensively mass produced

\subsection{Strategy considerations for ORV targeting terrestrial carnivores}

Access to highly immunogenic oral vaccines, together with optimal baits for their delivery, are critical strategic components to ORV. Nevertheless, there is a myriad of spatial, temporal, environmental and other issues that also impact ORV effectiveness. Although it is not within the scope of this paper to discuss these in detail, some of the more important strategy issues include: time of year to conduct ORV, annual frequency of ORV, bait density, baiting distribution patterns, non-target competition for baits, and habitat-specific preferences of reservoir species. The presence of extraordinarily high population densities of raccoons (Riley et al., 1998) and other rabies reservoir species, often in suburban or park settings, will continue to represent a strong challenge to achieving rabies management goals. Meeting long-range goals may require a paradigm shift from ORV as a single tactic toward evaluation of integrated strategies that may include contraception, reduction in access to food subsidies (i.e., reduced habitat carrying capacity for rabies reservoir species in specific environments) and focal population suppression. While studies have focused on some of these issues in North America, site specific and regional influences associated with these variables are not well documented.

\subsection{Potential for rabies translocation}

Prior to 1977 , raccoon rabies was confined to the southeastern U.S., primarily Florida and Georgia (Bigler et al., 1973). From 1977 to mid-1983, a total of 1608 raccoon rabies cases was reported from Washington, D.C. and West Virginia, Virginia, Maryland and Pennsylvania (Beck, 1984). The probable origin of this epizootic was the translocation of raccoons infected with rabies from the southeastern U.S., to 
the mid-Atlantic region, where the raccoon variant of rabies virus had not previously been reported (Nettles et al., 1979). Results from monoclonal antibody analysis of virus samples from the mid-Atlantic region of the U.S.A. were identical to the variant of rabies virus obtained from rabid raccoons in the southeastern states of the U.S.A. (Smith et al., 1984).

Translocation of raccoons or other rabies reservoir species can accelerate the rate of spread for rabies (as well as other diseases) and seriously jeopardize intervention strategies with ORV designed to create immune buffer zones to contain rabies spread (Smith et al., 2002). Translocation could undermine the commitment of tens of millions of dollars in state, provincial and federal funds to prevent raccoon or other variants of rabies from spreading.

The Communications Planning Team has taken the initiative to work closely with state wildlife, agriculture and public health officials to develop communication strategies to reach key audiences such as dog trainers, hunters, trappers, nuisance wildlife control operators, and wildlife rehabilitators on the negative impacts of translocation. The immediate goal is to reduce translocation of rabies reservoir species in the proximity of ORV zones. This will be a daunting task as translocation, in spite of its many potentially negative consequences (Frampton and Webb, 1973; Wright, 1977; Nettles et al., 1979; Talyor and Pelton, 1979; Rosatte and MacInnes, 1989; Mosillo et al., 1999), has become a common practice in many areas of North America (Craven et al., 1998).

\subsection{Bat rabies-a potential confounding rabies control factor}

The prospect of effective ORV programs for insectivorous bats appears remote at this time, given the need for novel, coordinated strategies to reach commensal species. For example, bats have virtually unlimited access to refuge in houses and other dwellings, and this is but one of several challenges. Nevertheless, transmission of rabies from bats to terrestrial carnivores may be the source for some extant rabies variants in carnivores (Badrane and Tordo, 2001), adding to the complexity of achieving long-term rabies management goals for terrestrial rabies. Documentation of big brown bat (Eptesicus fuscus) rabies virus spillover into skunks near Flagstaff, Arizona, with up to 19 skunks infected prior to intervention of the TVR (Engeman et al., 2003), represented an unprecedented contemporaneous event supporting the thesis that terrestrial rabies variants could evolve from virus host shifts from bats to terrestrial carnivores (Badrane and Tordo, 2001; Hughes et al., 2004). Adequate enhanced surveillance (i.e., beyond public health surveillance focused on potential or actual human exposures to the rabies virus) and differential virus strain diagnosis in bats and carnivores will continue to be required to trigger implementation of ORV contingency plans to address potential emergence of new terrestrial variants of the rabies virus.

\subsection{Economic basis for rabies funding}

Large-scale ORV began with state funded programs in Texas in 1995 (Fearneyhough et al., 1998) and Ohio in 1997 (Smith et al., 1999). Incremental successes in eliminating coyote rabies in Texas (Fearneyhough et al., 1998) and in preventing the westward spread of raccoon rabies through Ohio were catalysts for increased federal funding, which led to more diverse partnerships involving additional states, CDC, APHIS-WS and universities. Federal funding is critical to provide the necessary expertise, resources and coordination among states that have varying levels of rabies infrastructure and funding.

ORV is expensive to implement. Costs are incurred for bait production, air time for bait deployment, fuel, ground baiting, surveillance, and project planning and evaluation. Costs are dominated by the unit cost of bait/vaccine, currently priced at $\$ 1.27 / \mathrm{FMP}$ bait or $\$ 1.00 / \mathrm{CS}$. Based on 2003 contracts for the distribution for 4.23 million baits targeting raccoons along the Appalachian Ridge, which includes portions of Pennsylvania, Ohio, Maryland, West Virginia, Virginia and Tennessee, bait, air time and fuel costs were $\$ 5.38, \$ 0.69$, and $\$ 0.11$ millions, respectively (Table 4). Costs were $\$ 96 / \mathrm{km}^{2}$ for areas treated at an actual mean bait density of $66 / \mathrm{km}^{2}$; target bait density was $75 / \mathrm{km}^{2}$. Current average costs for these critical strategic components are lower than previously reported estimates (Uhaa et al., 1992; Foroutan et al., 2002; Kemere et al., 2002) in large part as a result of the recent expanded scope of ORV, which facilitated negotiation of more favorable contract pricing.

Benefits are largely driven by the expected savings from reduced costs associated with the burden of disease, such as minimizing exposure from fewer rabid animal encoun-

Table 4

Summary of costs for baits, air time and fuel to aerially distribute 4.23 million oral rabies vaccine baits along the Appalachian Ridge barrier in 2003 (baits cost $\$ 1.27$ each)

\begin{tabular}{|c|c|c|c|c|c|}
\hline State & No. of baits distributed & Bait (\$) & Air time $(\$)$ & Fuel (\$) & Area treated $\left(\mathrm{km}^{2}\right)$ \\
\hline MD & 47711 & 60593 & 13829 & 1722 & 689 \\
\hline $\mathrm{OH}$ & 536908 & 681873 & 86928 & 12208 & 8156 \\
\hline PA & 1421517 & 1805327 & 246847 & 33922 & 21518 \\
\hline $\mathrm{TN}$ & 180000 & 228600 & 32343 & 6447 & 2734 \\
\hline VA & 373227 & 473998 & 56729 & 11108 & 5669 \\
\hline WV & 1674505 & 2126621 & 257627 & 47087 & 25356 \\
\hline Total & 4233868 & 5377012 & 694303 & 112494 & 64122 \\
\hline
\end{tabular}


ters, and hence postexposure prophylaxis (PEP) (Krebs et al., 1998). Approximately 20,000 to 40,000 people annually receive PEP in the U.S., and even a single rabid animal may potentially expose hundreds of people, resulting in millions of dollars for biologicals alone (Noah et al., 1996). The most recent estimate for the cost of PEP and indirect patient costs of receiving treatment is about \$3350 (\$2250 PEP and $\$ 1100$ indirect costs) (Shwiff et al., 2003). This cost does not take into account other indirect costs, many of which are borne by municipal, county, state and federal agencies responsible for rabies control. The overall cost of living with all strains of rabies in the U.S. has been conservatively estimated to be $\$ 300$ million/year (Krebs et al., 1995).

Application of coordinated ORV to prevent raccoon rabies from spreading beyond its current distribution appears costbeneficial based on the robust economic analysis (Kemere et al., 2002). However, future analyses need to more realistically model spatial scenarios for the spread of raccoon rabies in the absence of ORV intervention as well as address other assumptions that facilitated this analysis. Moreover, elimination strategies that are designed to create rabies free areas where the virus has been established will require sufficient resources to leave immune buffers to prevent spread to new areas. The economic dynamic of such a strategy has not been evaluated in detail. Given that costs are and will remain a central issue to ORV, the National Economic Team has provided guidance and recommended funding for five economic analyses or related modeling studies to better characterize the economic dynamics of rabies and rabies control and the associated risks in the absence of intervention. The team will continue to consider how to best approach economic analyses for elimination strategies.

The goals of containing and eliminating specific variants of the rabies virus require strategic application of the limited resources available for ORV. Even when applied in combination with effective natural barriers and enhanced surveillance, progress may be expected in reasonably small increments along portions of the barrier, as federal and cooperator funds are not likely to become available to treat entire regions in single baiting campaigns. In 2003, almost $111,000 \mathrm{~km}^{2}$ were treated for raccoon rabies (Table 2). This is a substantial accomplishment toward containing raccoon rabies, but to have a better chance for sustained and perhaps increased access to federal and state resources, more rapid successes are needed to demonstrate that elimination of raccoon rabies is practical. This accomplishment would result in freeing resources committed to areas currently being treated such that they may be applied in new areas requiring vaccination.

\section{Collaboration and cooperation among Canada, Mexico and the United States}

To achieve rabies management goals, cooperation, coordination and collaboration are required among Canada, Mexico, and the U.S. Spillover of canine rabies, enzootic in Mex- ico, into coyotes and the subsequent outbreak in south Texas in the 1990s (CDC, 1995); spread of rabies in red foxes into northern New York and New England as recently as the early 1990s (Trimarchi, 1991); movement of the raccoon variant of rabies virus into southern Ontario in 1999 (Rosatte et al., 2001); and the movement of raccoon rabies into eastern New Brunswick in 2000 (Allen, pers. com.) are recent events that underscore the need for a viable North America Rabies Management Plan. Currently, APHIS-WS has an extended Environmental Assessment that serves, in large part, as a national ORV plan. This document, along with APHIS-WS Rabies Business Plan and other key national efforts such as the planning process conducted at CDC beginning in the early 1990s covering the broader spectrum of rabies issues (Hanlon et al., 1999a,b,c-Special Series Articles I, II and III), will serve as foundation references to solidify a National Plan within the NEPA process (NEPA, 1969). The National Rabies Management Plan will in turn allow for integration of input from Canada and Mexico to form the basis for the North American Rabies Management Plan.

\section{Conclusions}

Progress has been made in applying ORV to contain and eliminate some strains of terrestrial rabies in North America. Notable examples include near elimination of rabies from red foxes in southern Ontario (MacInnes et al., 2001), containment and elimination of canine rabies in coyotes from south Texas (Fearneyhough et al., 1998; Sidwa, pers. com.), containment and near elimination of raccoon rabies from Ohio (Krebs et al., 2002), prevention of raccoon rabies spread through the Lake Champlain Valley in New York and across northern Vermont and New Hampshire (Bigler, pers. com.) and reduced incidence of rabies cases where other sizable ORV projects targeting raccoons have occurred (Krebs et al., 2002). In February 2004, raccoon rabies was detected on the oceanside of the Cape Cod Canal, an anchor point for an ORV effort that began in 1994. Contingency baiting and TVR have been implemented to attempt to contain this expanded spread of raccoon rabies. In 2003, there were 23 cases in the Cape Cod ORV barrier, suggesting a formidable epizootic challenge to the barrier, which ranged in width from 5 to $29 \mathrm{~km}$. Both Ontario and New Brunswick have been raccoon rabiesfree for greater than 10 months and 2 years, respectively, after implementation of "point infection control" strategies (Rosatte et al., 2001), but continued surveillance is critical to monitor project effectiveness. An ORV zone established in northwest Georgia, southeast Tennessee, and northeast Alabama in 2003 was in response to enhanced surveillance suggesting that intervention with ORV was the prudent action to prevent raccoon rabies moving westward.

Many challenges have been identified. Initiatives have been taken toward: evaluation and development of new, more effective oral vaccines and baits; a more comprehensive understanding of rabies reservoir species population structure 
and dynamics in relation to ORV strategies; reduced translocation of rabies reservoir species; an applied understanding of the economic costs and benefits of ORV intervention; and enhanced coordination on rabies control in North America. New challenges will arise, emphasizing the critical niche that is filled by the interdisciplinary Rabies Management Team in planning future program direction.

\section{References}

Aubert, M.F., Masson, E., Artois, M., Barrat, J., 1994. Oral wildlife rabies vaccination field trials in Europe, with recent emphasis on France. Curr. Top. Microbiol. Immun. 187, 219-243.

Badrane, H., Tordo, N., 2001. Host switching in Lyssavirus history from the Chiroptera to the Carnivora orders. J. Virol. 75, 8096-8104.

Baer, G.M., Abelseth, M.K., Debbie, J.G., 1971. Oral vaccination of foxes against rabies. Am. J. Epidemiol. 93, 487-490.

Beck, A., 1984. An epizootic of rabies. Nat. Hist. 93, 7-11.

Bigler, W.J., Mclean, R.G., Trevino, H.A., 1973. Epizootiologic aspects of raccoon rabies in Florida. Am. J. Epidemiol. 98, 326-335.

Bigler, L., 1997. Oral rabies vaccination of raccoons in the St. Lawrence, Niagara, and Erie regions of New York State and the Champlain region of Vermont. In: Proceedings of the Eighth Annual International Meeting on Research Advances and Rabies Control in the Americas, Peterborough, Ontario, CA (abstract).

CDC, 1994. Human Rabies-Alabama, Tennessee, and Texas 44, 269-272.

CDC, 2003a. Update: adverse events following civilian smallpox vaccination-United States. MMWR 52, 819-820.

CDC, 2003b. Update: multistate outbreak of monkeypox-Illinois, Indiana, Kansas, Missouri, Ohio, and Wisconsin. MMWR 52, 642-646.

Craven, S., Barnes, T., Kania, F., 1998. Toward a professional position on the translocation of problem wildlife. Wildl. Soc. Bull. 26, 171-177.

Dietzschold, B., Faber, M., Schnell, M.J., 2003. New approaches to the prevention and eradication of rabies. Expert Rev. Vaccines 2, 399-406.

Engeman, R.M., Christensen, K.L., Pipas, M.J., Bergman, D.L., 2003. Population monitoring in support of a rabies vaccination program for skunks in Arizona. J. Wildl. Dis. 39, 746-750.

Fearneyhough, M.G., Wilson, P.J., Clark, K.A., Smith, D.R., Johnston, D.H., Hicks, B.N., Moore, G.M., 1998. Results of an oral rabies vaccination program for coyotes. J. Am. Vet. Med. Assoc. 212, 498-502.

Foroutan, P., Meltzer, M.I., Smith, K., 2002. Cost of distributing oral raccoon rabies vaccine in Ohio: 1997-2000. J. Am. Vet. Med. Assoc. 220, 27-32.

Frampton, J.E., Webb, L.G., 1973. Preliminary report on the movement and fate of raccoons released in unfamiliar territory. In: Proceedings of the Annual Conference of the Southeastern Association of Fish and Wildlife Agencies, vol. 27, pp. 170-183.

Guerra, M.A., Curns, A.T., Rupprecht, C.E., Hanlon, C.A., Krebs, J.W., Childs, J.E., 2003. Skunk and raccoon rabies in the eastern United States: temporal and spatial analysis. Emerg. Inf. Dis. 9, 1143-1150.

Hanlon, C.A., Rupprecht, C.E., 1998. In: Emerging Infections, W.M., Scheld, D., Armstrong, J.M., Hughes (Eds.), The Reemergence of Rabies. ASM Press, Washington, DC, pp. 59-80.

Hanlon, C.A., Niezgoda, M., Hamir, A.N., Schumacher, C., Koprowski, H., Rupprecht, C.E., 1998. First North American field release of a vaccinia-rabies glycoprotein recombinant virus. J. Wildl. Dis. 34 , 228-239.

Hanlon, C.A., Olson, J.G., Clark, C.J., The National Working Group on Rabies Prevention and Control, 1999a. Special series-recommendations of a national working group on prevention and control of rabies in the United States. Article I. Prevention and education regarding rabies in human beings. J. Am. Vet. Med. Assoc. 215, 1276-1281.
Hanlon, C.A., Smith, J.S., Anderson, G.R., The National Working Group on Rabies Prevention and Control, 1999b. Special series-recommendations of a national working group on prevention and control of rabies in the United States. Article II. Laboratory diagnosis of rabies. J. Am. Vet. Med. Assoc. 215, 1444-1447.

Hanlon, C.A., Childs, J.E., Nettles, V.F., The National Working Group on Rabies Prevention, Control, 1999c. Special series-recommendations of a national working group on prevention and control of rabies in the United States. Article III. Rabies in wildlife. J. Am. Vet. Med. Assoc. 215, 1612-1619.

Hughes, G.J., Smith, J.S., Hanlon, C.A., Rupprecht, C.E., 2004. Evaluation of a TaqMan PCR assay to detect rabies virus RNA: influence of sequence variation and application to quantification of viral loads. J. Clin. Microbiol. 42, 299-306.

Kemere, P., Liddel, M.K., Evangelou, P., Slate, D., Osmek, S., 2002. Economic analysis of a large-scale oral vaccination program to control raccoon rabies. In: Clark, L. (Ed.), Human Conflicts with Wildlife: Economic Considerations. National Wildlife Research Center, Fort Collins, CO, pp. 109-116.

Krebs, J.W., Strine, T.W., Smith, J.S., Rupprecht, C.E., Childs, J.E., 1995. Rabies surveillance in the United States during 1994. J. Am. Vet. Med. Assoc. 207, 1562-1575.

Krebs, J.W., Long-Martin, S.C., Childs, J.E., 1998. Causes, costs, and estimates of rabies postexposure prophylaxis treatments in the United States. J. Public Health Manage. Pract. 4, 56-62.

Krebs, J.W., Mondul, A.M., Rupprecht, C.E., Childs, J.E., 2002. Rabies surveillance in the United States during 2001. J. Am. Vet. Med. Assoc. $221,1690-1701$.

MacInnes, C.D., LeBer, C.A., 2000. Wildlife management agencies should participate in rabies control. Wildl. Soc. Bull. 28, 1156-1167.

MacInnes, C.D., Smith, S.M., Tinline, R.R., Ayers, N.R., Bachmann, P., Ball, D.G.A., Calder, L.A., Crosgrey, S.J., Fielding, C., Hauschildt, P., Honig, J.M., Johnston, D.H., Lawson, K.F., Nunan, C.P., Pedde, M.A., Pond, B., Stewart, R.B., Voigt, D.R., 2001. Elimination of rabies from red foxes in eastern Ontario. J. Wildl. Dis. 37, 119-132.

Mosillo, D.W., Heske, E., Thompson, J., 1999. Survival and movements of translocated raccoons in north central Illinois. J. Wildl. Manage. 63, 278-286.

Nadin-Davis, S.A., Sampath, M.I., Casey, G.A., Tinline, R.R., Wandeler, A.I., 1999. Phylogoegraphic patterns exhibited by Ontario rabies virus variants. Epidemiol. Infect. 123, 325-336.

Nettles, V.F., Shaddock, J.H., Sikes, R.K., Reyes, C.R., 1979. Rabies in translocated raccoons. Am. J. Public Health 69, 601-602.

NEPA, 1969. National Environmental Policy Act (42 U.S.C. 4321 et seq.).

Noah, D.L., Smith, M.G., Gotthardt, J.C., Krebs, J.W., Green, D., Childs, J.E., 1996. Mass human exposure to rabies in New Hampshire: exposures, treatment and cost. Am J. Public Health 86, 1149-1151.

Olson, C.A., Mitchell, K.D., Werner, P.A., 2000. Bait ingestion by freeranging raccoons and non-target species in an oral rabies vaccine field trial in Florida. J. Wildl. Dis. 36, 734-743.

Riley, S.P., Hadidian, J., Manski, D., 1998. Population density, survival, and rabies in raccoons in an urban national park. Can. J. Zool. 76, 1153-1164.

Robbins, A.H., Borden, M.D., Windmiller, B.S., Niezgoda, M., Marcus, L.C., O’Brien, S.M., Kreindel, S.M., Mcguill, M.W., Demaria Jr., A., Rupprecht, C.E., Rowell, S., 1998. Prevention of the spread of rabies to wildlife by oral vaccination of raccoons in Massachusetts. J. Am. Vet. Med. Assoc. 213, 1407-1412.

Rosatte, R., MacInnes, C.D., 1989. Relocation of city raccoons. Proc. Great Plains Workshop 9, 87-92.

Rosatte, R., Donovan, D., Allan, M., Howes, L.A., Silver, A., Bennett, K., MacInnes, C., Davies, C., Wandeler, A., Radford, B., 2001. Emergency response to raccoon rabies introduction into Ontario. J. Wildl. Dis. 37, 265-279.

Roscoe, D.E., Holste, W.C., Sorhage, F.E., Campbell, C., Niezgoda, M., Buchannan, R., Diehl, D., Niu, H.S., Rupprecht, C.E., 1998. Efficacy of an oral vaccinia-rabies glycoprotein recombinant vaccine in con- 
trolling epidemic raccoon rabies in New Jersey. J. Wildl. Dis. 34, 752-763.

Rupprecht, C.E., Blass, L., Smith, K., Orciari, L.A., Niezgoda, M., Whitfield, S.G., Gibbons, R.V., Guerra, M., Hanlon, C.A., 2001. Human infection due to recombinant vaccinia-rabies glycoprotein virus. $\mathrm{N}$. Engl. J. Med. 345, 582-586.

Shwiff, S.A., Sterner, R.T., Jay-Russell, M., Parikh, S., Bellomy, A., Slate, D., 2003. Estimating the direct and indirect cost of rabies postexposure prophylaxis. In: Proceedings of the 14th Annual International Meeting on Research Advances and Rabies Control in the Americas, Philadelphia, PA, p. 75 (abstract).

Slate, D., Chipman, R.B., Rupprecht, C.E., DeLiberto, T., 2002. Oral rabies vaccination: a national perspective on program development and implementation. In: Timm, R.M., Schmidt, R.H. (Eds.), Proceedings of the 20th Vertebrates Pest Conference. University of California, Davis, pp. 232-240.

Smith, J.S., Sumner, J.W., Roumillat, L.F., Baer, G.M., Winkler, W.G., 1984. Antigenic characteristics of isolates associated with a new epizootic of raccoon rabies in the United States. J. Infect. Dis. 149, 769-774.

Smith, K., Krogwold, A., Smith, R., Hale, F., Collart, R., Craig, M., 1999. The Ohio ORV program. In: Proceedings of the 10th International Meeting on Research Advances and Rabies Control in the Americas, San Diego, CA (abstract)

Smith, D.L., Lucey, B., Waller, L.W., Childs, J.E., Real, L.A., 2002. Predicting the spatial dynamics of rabies epidemics on heterogeneous landscapes. PNAS 99, 3668-3672.

Steck, F., Wandeler, A., BichseL, P., Capt, S., Hafliger, U., Schneider, L.G., 1982. Oral immunization of foxes against rabies. Laboratory and field studies. Comp. Immunol. Microbiol. Infect. Dis. 5, 165-171.

Stohr, K., Meslin, F.M., 1996. Progress and setbacks in the oral immunization of foxes against rabies in Europe. Vet. Rec. 139, 32-35.
Talyor, C.I., Pelton, M.R., 1979. Evaluation of raccoon translocation attempt in east Tennessee. Proc. Ann. Conf. Southeastern Assoc. Fish and Wildl. Agencies 33, 187-194.

Trimarchi, C.V., 1991. 1990 rabies annual summary. New York State Vet. News 55, 4.

Tolson, N.D., Charlton, K.M., Stewart, R.B., Campbell, J.B., Wiktor, T.J., 1987. Immune response in skunks to a vaccinia virus recombinant expressing the rabies virus glycoprotein. Can. J. Vet. Res. 51, 363 366.

Uhaa, I.J., Dato, V.M., Sorhage, F.E., Beckley, J.W., Roscoe, D.E., Gorsky, R.D., Fishbein, D.B., 1992. Benefits and costs of using an orally absorbed vaccine to control rabies in raccoons. J. Am. Vet. Med. Assoc. 201, 1873-1882.

USDA, 2003. Cooperative rabies management program national report 2002 (un-numbered report). APHIS, Wildlife Services, pp. 65.

Van Regenmortel, M.H.V., Fauquet, C.M., Bishop, D.H.L., Carstens, E.B., Estes, M.K., Lemon, S.M., Maniloff, J., Mayo, M.A., McGeoch, D.J., Pringle, C.R., Wickner, R.B., 2000. Virus Taxonomy: Seventh Report of the International Committee on Taxonomy of Viruses. Academic Press, San Diego, CA.

Wandeler, A.I., 2000. Oral immunization against rabies: afterthoughts and foresight. Schweiz. Arch. Tierheilkd. 142, 455-462.

Wright, G.A., 1977. Dispersal and survival of translocated raccoons in Kentucky. Proc. Ann. Conf. Southeastern Assoc. Fish Wildl. Agencies 31, 285-294.

Yarosh, O.K., Wandeler, A.I., Graham, F.L., Campbell, J.B., Prevec, L., 1996. Human adenovirus type 5 vectors expressing rabies glycoprotein. Vaccine 14, 1257-1264.

Zanoni, R.G., Kappeler, A., Muller, U.M., Muller, C., Wandeler, A.I., Breitenmoser, U., 2000. Rabies-free status of Switzerland following 30 years of rabies in foxes. Schweiz. Arch. Tierheilkd. 142, 423429. 